University for Business and Technology in Kosovo

UBT Knowledge Center

Oct 27th, 1:30 PM - 3:00 PM

\title{
Europeanization of the Balkans vs. Balkanization of Europe: A Vision Limited by Realities
}

\author{
Abdullah Sencer Gözübenli \\ Mother Teresa University, a.sencer.g@gmail.com \\ Nazli Tekeshanoska \\ Mother Teresa University, naz.tekke@gmail.com
}

Follow this and additional works at: https://knowledgecenter.ubt-uni.net/conference

Part of the Political Science Commons

\section{Recommended Citation}

Gözübenli, Abdullah Sencer and Tekeshanoska, Nazli, "Europeanization of the Balkans vs. Balkanization of Europe: A Vision Limited by Realities" (2018). UBT International Conference. 390.

https://knowledgecenter.ubt-uni.net/conference/2018/all-events/390

This Event is brought to you for free and open access by the Publication and Journals at UBT Knowledge Center. It has been accepted for inclusion in UBT International Conference by an authorized administrator of UBT Knowledge Center. For more information, please contact knowledge.center@ubt-uni.net. 


\title{
Europeanization of the Balkans vs. Balkanization of Europe: A Vision Limited by Realities
}

\author{
Abdullah Sencer Gözübenli ${ }^{1}$, Nazli Tekeshanoska ${ }^{2}$ \\ ${ }^{1}$ Ss. Cyril and Methodius University in Skopje, Institute for Sociological, Political and Juridical \\ Research, Skopje, Republic of Macedonia \\ ${ }^{2}$ International Balkan University, Skopje, Republic of Macedonia \\ $\left\{\right.$ a. sencer. $g^{1}$, naz. tekke $\left.{ }^{2}\right\}$ @gmail.com
}

\begin{abstract}
After decades out of the radar, Western Balkans entered on the agenda of European Community simultaneously with the collapse of the Socialist Federal Republic of Yugoslavia and the Union of Soviet Socialist Republics at the end of 80s. The 90s brought back the focus at the EU enlargement, creating new political momentum with new approaches in European Integration. Finally, 13 Central and Eastern European Countries became members of the EU in last two decades. The most-awaited new Enlargement Strategy for the remaining potential candidate and candidate countries in the Western Balkans, entitled "The Credible Enlargement Perspective for the Western Balkans" was presented earlier this year. The strategy that was presented eighteen years after the launch of the Stabilisation and Association Process (SAP), indicates a clear prospect of accession of Western Balkans countries to the EU by the end of 2025. It is clear that Western Balkans needs the EU for more stability and less corruption, however for us, social acceptability of nationalism and far-right in the Western Europe is a danger for Western Balkans countries that were torn by sharp ethnic conflicts until recently. On the other hand, some Central European countries' descent into authoritarianism is another problem for sensitive stability of Western Balkans countries on the door of the EU. This study aims to take a comprehensive look at how Europe is Balkanizing while Western Balkans countries are Europeanizing. Some specific cases will be analyzed dealing with the rise of Nationalism and Authoritarianism in Europe and European Integration of Western Balkans countries.
\end{abstract}

Keywords: European Integration, Freedom of Movement, Nationalism, Western Balkans. 


\section{Introduction}

The break-up of multinational state of Socialist Federal Republic of Yugoslavia (SFRY), disintegrated the Yugoslav citizenship regime, and eroded the existing stability and balance in the region. As a result of the disintegration, new countries with new communities were born in the South Eastern borders of the European Union (EU). With this anticipated situation, the EU commenced an important relationship with the post-communist Central and Eastern European Countries (CEECs) including Western Balkans countries (WBCs). The EU had fully supported marketization, stabilization and democratization of these countries, at the beginning of the 90s. It has emerged as the primary actor in so-called state-building process in the Western Balkans, as Bieber points out. [1] During turbulent years for Western Balkans in the 90s, it is clear that the EU more likely acted as a mediator in civil conflicts while signing European Agreements with these countries that aimed accelerating trade liberalization and establishing free trade arrangements between the European Community and the CEECs. [2][3]

Following Serbia's campaign of aggression in Kosovo from 1998 to 1999, the EU established in June 1999 a new enlargement policy and post-conflict management instrument towards the Western Balkans countries called "Stabilisation and Association Process" (SAP) which was strengthened at the EU-Western Balkans Summit, held 21 June 2003 in Thessaloniki. In this context, Stabilisation and Association Agreements (SAA), which aim at implementing SAP to secure well-functioning democratic societies in WBCs with a view to EU membership, were signed between the EU and WBCs. [4] Finally, all the WBCs were recognized as potential candidates for EU membership by the Feira European Council, held in northern Portugal on 19-20 June 2000. [5] It is clear that the Europeanization of Western Balkans started to include the effect of the EU-linked reforms within the countries' national politics and policy-making with this enlargement process.

Fifteen years ago, EU leaders told their counterparts from Western Balkans in Thessaloniki, that their countries belong to Europe and their countries could one day join the EU. [6] Despite the fact that the Republic of Macedonia became the first country among the Western Balkans region to sign a SAA, that was followed by Croatia (2001), Albania (2006), Montenegro (2007), Bosnia and Herzegovina (2008), Serbia (2008) and finally Kosovo (2015) [4][7], only one of those countries, Croatia, has become an EU member and the Republic of Macedonia (in future the country will be called the Republic of North Macedonia) has not yet entered into accession negotiations because its accession was blocked by Greece's dispute over the country's name, despite that it has been recommended for accession negotiations nine times since 2005. On the other hand, Kosovo, which did not exist as an independent state during the Thessaloniki Talks, is now in front of the EU's door. While this paper was being prepared, European Parliament (EP) has voted in favour of Kosovo having a visa-free regime with the EU's passport-free Schengen area [8] and the referendum about the new name of Macedonia (North Macedonia) in which citizens expressed their support for NATO and EU membership by accepting the Prespa Agreement between Macedonia and Greece, which took place September 30th, 2018, ended in failure according 
to the constitution by a low turnout of $36.9 \%$ despite close to $91.46 \%$ of a "Yes" vote. [9] Five days later, the President of the European Commission Jean-Claude Juncker said full membership for WBCs is not expected before 2025 and he underlined that there is a danger of new conflicts in the Balkans, if the WBCs are left without European perspective. [10]

Most WBCs are today between stabilitocracy ${ }^{1}[11]$ and hybrid democracies, aspiring to join the EU, while they are watching Hungarian President Viktor Orbán's illiberal tendencies inside EU borders. The European Parliament has voted to trigger EU's most serious disciplinary procedure against Hungary, saying the country's government poses a "systematic threat" to democracy and the rule of law. [12]

Marie Le Pen who was the leader of anti-Islam and anti-immigration National Front, won $18 \%$ of votes in the French presidential elections in 2012. Similar parties with right-wing extremist orientations and programs exist in Austria, Switzerland, Italy, Belgium and a part of them are represented by its members in the ruling coalitions. [13] Austria came close to becoming the first EU country to elect a far-right head of state, Norbert Hofer, the anti-establishment Five Star Movement and right-wing League have gone into coalition in Italy and governments in Poland and Hungary dismantling democratic institutions. The Brexit vote in the UK constitutes the first popular decision of a member state to leave the EU. [14]

The WBCs are scarred by important structural problems inherited from its communist past and the growing support for far-right and anti-EU political movements in EU Member States makes the decision-making process regarding the accession processes of the WBCs unpredictable and volatile. [15] The xenophobic and illiberal governments in the CEECs remind the WBCs their autocratic practices in the past.

The main objective of this paper is to assess the credibility of the EU in the WBCs while the EU is offering a credible enlargement perspective for Western Balkans.

\section{Europeanization of the Balkans: From Mediation to State- building}

Since the dispersion of the SFRY, the WBCs stand at the shore of the island of freedom, stability, democracy and prosperity - that is called the EU - having received significant attention from the island. The EU has sought to foster peace, stability and prosperity in post-Communist countries by exporting its norms and principles to repair the devastating damage of the communist regimes and to create a common area of freedom and stability in the region. The dissolution of the Soviet Union and SFRY

\footnotetext{
${ }^{1}$ Bieber and Kmezić, in the BiEPAG policy brief entitled "The Crisis of Democracy in the Western Balkans. An Anatomy of Stabilitocracy and the Limits of EU Democracy Promotion", used the term "Stabilitocracy" to describe the semi-authoritarian regimes in the WBCs which receive external support in particular from the EU member states for the sake of so-called promise of (negative) stability. (See. Kmezić, M., Bieber, F.: The Crisis of Democracy in the Western Balkans: An Anatomy of Stabilitocracy and the Limits of EU Democracy Promotion. (2017)).
} 
began almost simultaneously and under similar circumstances. However, while the anti-communist revolutions lead to the relatively peaceful break-up of the Eastern Bloc, SFRY spiraled downwards into bloody nationalist conflicts. So the EU's strategic approaches to CEECs and WBCs were different. It can be argued that types of communism the two regions experienced, and the EU's political elites' roles on both regions, are different. There are different types of integration for different types of post-communist states within the framework of the EU which are supposed to lead to diverse mechanisms of Europeanization. The collapse of the communist regimes in the CEECs was accompanied by a deep social crisis, and systemic change has produced a new one in turn. In fact, beyond this, the entire process resulted in a singular contradiction. The exclusion of the impoverished masses from politics has been the price paid for the survival of democratization while avoiding the danger of populism. On the other hand, during the turbulent years surrounding the collapse of the SFRY at the beginning of 90s and the bloody civil war that followed, the EU acted as a mediator in civil conflicts in accordance with its joint goals of establishing peace and prosperity throughout Europe. Managing these conflicts has long been a strategic priority for the EU and the EU addressed these disputes as European issues. By doing so, the EU pursued a two-track approach by providing proactive mediation, and then by securing resources for mediation and the relaxation of relations between the disputing parties. WBCs that all are located within the continent of Europe are considered as potential EU members and a strategic priority. It can be argued that the EU drew on its enlargement approach in seeking to stabilize the WBCs, since the end of 90s. In this context, all WBCs have signed SAA with the EU over the last years, which legally bind them into a process of political and economic integration. [16]

In June 2000 the Feira European Council officially decided that all the SAP countries are potential candidates for EU membership that would meet the Copenhagen Criteria for effective and democratic governance. [17] Since then, the main instruments and practices used by the EU's policy through the WBCs have shifted from post-war stabilization to an agenda of enlargement. Next to membership conditionality, the EU employed a comprehensive toolbox of different instruments, including diplomacy, financial assistance (PHARE, ISPA, SAPARD, CARDS, IPA I, IPA II) ${ }^{2}$, and statebuilding supervision, to promote post-conflict stabilization and democratization.

After a decade and a half of integration and stabilization process, the so-called Eastern enlargement of the EU in 2004 followed by the accession of Bulgaria and Romania in 2007 made Europe 27, and this number increased to 28 when Croatia became the first country from Western Balkans to accede to the EU. With this accession, the EU became a direct neighbor of the Western Balkans.

On the other hand, despite the fact that the WBCs have all progressed on their paths to the EU membership during so-called Eastern enlargement, all WBCs were still postconflict societies and they have swung between reforms and instability, corruption,

\footnotetext{
${ }^{2} \mathrm{~A}$ series of EU programmes and financial instruments for candidate countries and potential candidate countries, namely; PHARE, ISPA, SAPARD, the Instrument for Pre-accession of Turkey, CARDS and IPA was provided to CEECs and enlargement countries by the EU to help the candidate and potential candidate countries to make political, economic and legal reforms, preparing them for the rights and obligations that come with EU membership.
} 
nationalist tensions and weak governance. While the EU was supporting the development of WBCs stable peace, economic prosperity and consolidated democracy, [18] in April 2007, the WBCs initialed visa facilitation agreements that allows more simplified procedures when applying for visas for entering the EU countries that was introduced at the Thessaloniki Summit in 2003. In this context, visa-free regimes with Schengen Area were approved to Montenegro, Macedonia and Serbia in 2009 and to Albania and Bosnia and Herzegovina in 2010. Kosovo is left the only country in the Western Balkans whose citizens still need visas to travel. ${ }^{3}$ These visa-free regimes for the citizens of the WBCs is to set the stage for the first contact between the EU and WBCs citizens, as so far Europeanization arrangements of the WBCs have mainly included governmental arrangements rather than arrangements at the local level. This can be called as Grassroots Europeanization or human-to-human integration.

The recent result of this grassroots approach is the result of recent referendum in which voters were asked whether they support EU and NATO membership, took place in Macedonia. The results showed that $91.4 \%$ voted in favour of changing the country's name for Macedonia's possible entrance into NATO and the EU, and they confirmed that the people of the region strongly support the EU integration of their countries as Keil and Arkan points out. [19]

\subsection{Next Stop " 2025 "}

Earlier this year the EU pushed for major changes in state-building and bilateral and regional cooperation within the agenda of enlargement, when it turned from outward to inward interests after a decade of economic and so-called migration crises. The EU enlargement plan for the WBCs entitled "The Credible Enlargement Perspective for the Western Balkans" was presented by the European Commission in February 2018. The new strategy indicates a clear prospect of accession of Western Balkans countries to the EU by the end of 2025. The date 2025 is mentioned in the strategy in the following statement: "The Strategy explains the steps that need to be taken by Montenegro and Serbia to complete the accession process in a 2025 perspective; while others could catch up, Montenegro and Serbia are the only two countries with which accession talks are already under way." [20] In June 2018, after a lengthy debate, the EU Council agreed to open membership talks with Macedonia and Albania by the end of 2019. This perspective holds that the EU needed more time to absorb the addition of 13 new member states among the CEECs over the past decades and should not take in any new members until real and demonstrable consolidation has been achieved inside the EU. We should note that assessing the credibility of the enlargement perspective for the WBCs is beyond the scope of this study, but we need to underline that the strategy fails to address the involvement of five EU member states ${ }^{4}$ including Greece ${ }^{5}$

\footnotetext{
${ }^{3}$ While this paper was being prepared, EP has voted in favour of Kosovo having a visa-free regime with the EU's passport-free Schengen area. (See. 8)

${ }^{4}$ The EU states that do not recognize Kosovo's independence are Spain, Slovakia, Cyprus, Romania, and Greece.

5"The Credible Enlargement Perspective for the Western Balkans" was presented while the controversial name dispute between Greece and Macedonia was still ongoing.
} 
that doesn't recognize Kosovo, in accession talks that threatens the credibility of EU's enlargement perspective.

\section{Balkanization of the Europe: From Wall Destroying to Wall Building}

While Balkanization is a term used to describe the concept of division or disintegration of coexistent things from micro-level such as family or neighborhood to macrolevel such as state institutions, Europeanization is used in terms of integration or domestic adaptation. Europeanization is expected from Europe.

In his chapter "Why the EU needs Croatia (even more than Croatia needs the EU)" of the book "What Does Europe Want?" (written together with Slavoj Žižek), Croatian philosopher Srećko Horvat quotes a sentence from El Pais (2 May 2004); "by joining the EU, Slovenia escaped the Balkan curse". But if we take a closer look, Europe is 'Balkanized' already, and, on the other hand, the Balkans are 'Europeanized' as well, he adds. [21] After 14 years of EU Accession of Slovenia, right-wing populist party won most votes for the second time in Slovenian polls with an anti-migration discourse. While the EU was taking down walls towards the WBCs with liberalization of the EU's visa regime towards them, Hungary, a EU member state, built the wall along the EU country's border with Western Balkans during the so-called European migrant crisis. [22]

The rise of populism, instrumentalizing identity politics in some EU member states (especially in the CEECs), and illiberal turn in the Visegrád Four (V4) countries that formally commit to EU integration and internalize the reform discourse, have direct consequences for their neighboring WBCs and their EU enlargement process. On the other hand, European Conservatives' support of some strong illiberal and nationalist actors of the WBCs' who are self-proclaimed "reformer" political regimes ${ }^{67}$ (Gruevski in Macedonia, Dodik in Bosnia's autonomous Republika Srpska, Vučić in Serbia) $)^{8}$, can be interpreted as the European community undermining its credibility by

${ }^{6}$ Current PM of Austria Sebastian Kurz was accused of supporting authoritarianism after appearing at an election rally for Macedonia's ex-ruling VMRO-DPMNE party with Nikola Gruevski in November 2016. (See. http://www.balkaninsight.com/en/article/critics-slam-kurzs-support-for-macedonia-s-ruling-party-11-28-2016)

${ }^{7}$ Hungarian Anti-immigration leader Viktor Orbán and Slovenia's former Anti-immigration leader Janez Janša have given a hearty boost to Macedonia's ousted leader Nikola Gruevski in the run-up to Macedonia's local elections in October 2017.

(See. http://www.balkaninsight.com/en/article/orban-jansa-praise-macedonia-s-gruevskiduring-polls-09-29-2017)

${ }^{8}$ Over the duration of their rule, Nikola Gruevski in Macedonia and Milorad Dodik in Republika Srpska have taken a strong nationalist position and increasingly distanced themselves from Euro-Atlantic integration. Others, like Milo Đukanović in Montenegro or Aleksandar Vučić in Serbia have not.

(See. Bieber, F.: Patterns of competitive authoritarianism in the Western Balkans. East European Politics, 34:3, 337-354, DOI: 10.1080/21599165.2018.1490272 (2018)) 
choosing stability over democracy in WBCs. There is a growing concern in the EU about the democratic backsliding in the WBCs that are increasingly characterized by strong executives, weak parliaments, and political pressure on independent institutions, media, and civil society, while some EU members display comparable patterns of weak institutions, corruption and limited media freedom, such as Bulgaria. ${ }^{9}$

On the other side of the coin, while the far-right camps in the EU member states (Greece's neo-Nazi Golden Dawn party, Jobbik in Hungaria, Ataka in Bulgaria, Le Pen's Front National in France or Wilders' Freedom Party in the Netherlands etc.), in the effort to turn the global economic crisis that struck the Eurozone from the south to the opportunity with Goebbels' rhetorics, are getting stronger, some politicians in the WBCs that were mentioned above are using identity politics to mobilize their supporters and divert attention away from economic problems. It's clear that without the EU, identity issues could quickly spill over into radical nationalist movements and ethnic conflict in the WBCs that were torn by sharp ethnic conflicts until recently, as Juncker stated.

\section{Conclusion}

The impact of European populism in the WBCs can have potentially dangerous consequences considering that stabilitocracies, which have experiences instability, can be easily manipulated by safeguarding stability over pushing for democratic transition. Populist stability tactics of some CEECs undermines EU's credible perspective for the WBCs including promotion of democracy as its legitimacy and credibility are questioned. It can be said that the WBCs get trapped between the EU's credible approach preferring the deepening of the EU to its widening and Orban's pragmatic approach more interested in getting new friends in the EU in than in their economic and democratic transformation. The WBCs - in transition from the process of State-building to the process of Member-state building - as this point of time seem to be ready for the regional cooperation that is the major achievement of the Berlin Process. On the other hand, growing support for populism and far-right political movements in EU member states, makes the decision-making process regarding accession of the WBCs more unpredictable, considering accession decisions are taken by unanimity in the EU. European political parties should play a more constructive role in democratization efforts other than supporting authoritarianism in the WBCs.

\footnotetext{
${ }^{9}$ While this paper was being prepared, 30-year-old Journalist Viktoria Marinova was found dead in a park in Ruse, a northern border city of Bulgaria. She had recently covered suspected misuse of EU funds by businesses and local politicians. She is the third journalist to be murdered in the European Union in less than a year.

(See. https://www.independent.co.uk/news/world/europe/bulgaria-journalist-murder-viktoriamarinova-ruse-rape-corruption-investigation-eu-funds-tvn-a $8573686 . \mathrm{html}$ )
} 


\section{References}

1. Bieber, F.: Building impossible states? State-Building strategies and EU membership in the Western Balkans. Europe-Asia Studies 63(10): pp. 1783-1802. (2011)

2. Scalera, J. E., Wiegand, K. E.: The Motivation of. European Union Mediation in Civil Conflicts. European Union Studies Association Biennial Conference May 4-7, 2017 Miami, FL. (2017)

3. Karluk, R.: Avrupa Birliği'nin Balkanlara Genişlemesi: Balkan Ülkelerine ÜyelikPerspektifi, International Conference on Eurasian Economies, 1-3 July 2014 Skopje Macedonia, İstanbul. http://avekon.org/papers/1163.pdf. last accessed 11 September 2018

4. Gözübenli, A. Sencer.: Comparative Analysis on the Contribution of EU Pre-Accession Funds to the Republic of Macedonia and Montenegro in the Sector of Social Inclusion for the period 2007-2013, Unpublished Master's Thesis, TurgutÖzal University Graduate School of Social Sciences, Ankara, Turkey. (2016)

5. Karluk, S. R., Dervishi, B., Gözübenli, A. S..: Avrupa Birliği'nin Batı Balkanlara Genişlemesi: Emeklilik Reformları Özelinde Makedonya Cumhuriyeti'nin AB Adaylık Süreci Üzerine Bir İnceleme. In: INTOCBEPS II International Turgut Ozal Congress on Business Economics and Political Science Proceedings Book: Political Science and International Relations, pp. 87-92 Ankara, Turkey. (2016)

6. Gray, A.: 5 takeaways from EU's big Balkan get-together. Politico. https://www.politico.eu/article/eu-western-balkans-sofia-summit-takeaways-membershiptalk s-enlargement/ last accessed 11 September 2018

7. Uvalic, M.: EU Policies towards the Western Balkans: The Role of Sticks and Carrots. AISSEC Conference Paper, Perugia. (2009)

8. European Parliament, http://www.europarl.europa.eu/news/en/pressroom/20180918IPR13702/ep-and-kosovo-parliamentary-committee-hails-ep-vote-on-visaliberalisation, last accessed 2018/09/21

9. Државната изборна комисија на република македонија, $\mathrm{http}: / /$ referendum.sec.mk/Referendum/Results?cs=mk-MK\&r=r\&rd=r1, last accessed 2018/10/02

10. European Western Balkans, https://europeanwesternbalkans.com/2018/10/05/junckerwithout-european-perspective-military-conflicts-possible-balkans/, last accessed 2018/10/06

11. BiEPAG. The Crisis of Democracy in the Western Balkans. Authoritarianism and EU Stabilitocracy. Graz: BiEPAG. Bosse, Giselle. (2017). 
12. European Parliament, http://www.europarl.europa.eu/news/en/pressroom/20180906IPR12104/rule-of-law-in-hungary-parliament-calls-on-the-eu-to-act, last accessed 2018/09/21

13. Stevkovski, L.: The Rise of Right-Wing Extremism in European Union, International Studies. Interdisciplinary Political and Cultural Journal 17 (1):43-57 (2015)

14. Bieber, F., Kmezić, M.: Policy brief EU enlargement in the Western Balkans in a time of uncertainty, BiEPAG, September, 2016, 1-16. (2016)

15. Gustafson, O.: Responding to Populism, Nationalism, and Authoritarianism in the Western Balkans and Beyond. in: Esch V. \& Remme Y. (2017). (eds). A European Future for the Western Balkans - Addressing Political and Economic Challenges. The Aspen Institute. Available at: http://www.aspeninstitute.de/wp-content/uploads/A-European-Future-forthe-Western-Balkans.pdf. p.63. (2017)

16. Keil, S.: Europeanization, state-building and democratization in the Western Balkans. Nationalities Papers, 41:3, 343-353, DOI: 10.1080/00905992.2013.768977 (2013)

17. Bărbulescu, I.G., M. Troncotă. The Ambivalent Role of the EU in the Western Balkans Limited Europeanisation between Formal Promises and Practical Constraints. The Case of Bosnia-Herzegovina, Romanian Journal of European Affairs, 12:1 (2012)

18. Borzel, Tanja A., Grimm, S.: Building Good (Enough) Governance in Postconflict Societies \& Areas of Limited Statehood: The European Union \& the Western Balkans. Daedalus 147(1), 116-127 (2018)

19. Keil, S., Arkan, Z.: Theory and practice of EU member state building in the Western Balkans. In S. Keil and Z. Arkan (eds) The EU and Member State Building: European Foreign Policy in the Western Balkans. New York: Routledge, 15- 31. (2015)

20. European Commission - Press release. europa.eu/rapid/press-release_IP-18-561_en.htm last accessed 2018/09/21

21. Horvat, S.: Neden Hırvatistan'ın AB'ye İhtiyacı Olduğundan Çok AB'nin Hırvatistan'a İhtiyacı Var., In book: Avrupa Ne İstiyor? (Avrupa Birliği ve Onun Hoşnutsuzlukları) by Slavoj Žižek and Srećko Horvat, çev. Bora Vergili. Can Yayınları, İstanbul, (2015)

22. Gözübenli, A. S.: Landmines and Refugees: Out of the Frying Pan, into the Fire. Annual of ISPJR 2018 42(Special Issue), pp. 9-19, (2018) 